\title{
Factors controlling phytoplankton in tropical high-mountain drinking-water reservoirs
}

\author{
Nubia León López ${ }^{1}$, Carlos A. Rivera Rondón ${ }^{2,3, *}$, Ángela Zapata ${ }^{2,3}$, Jorge Jiménez ${ }^{3}$, William \\ Villamil $^{3}$, Gerardo Arenas ${ }^{1}$, Carlos Rincón ${ }^{1}$ and Tulio Sánchez ${ }^{1}$ \\ ${ }^{1}$ Empresa de Acueducto y Alcantarillado de Bogotá E.S.P., Calle 24 No. 37-15, Bogotá, Colombia. E-mail: \\ nleon@acueducto.com.co \\ ${ }^{2}$ Departamento de Biología, Pontificia Universidad Javeriana, Cra. 7. 40-82, Bogotá, Colombia. \\ ${ }^{3}$ Auditoría Ambiental LTDA., Bogotá, Colombia. \\ * Corresponding author: crivera@javeriana.edu.co
}

Received: $30 / 9 / 11 \quad$ Accepted: $3 / 7 / 12$

\begin{abstract}
Factors controlling phytoplankton in tropical high-mountain drinking-water reservoirs

Hydraulic dynamics is one of the primary factors determining the structural and temporal changes in phytoplankton communities in reservoirs. There is little information on the factors that explain the temporal changes in biotic communities in the high-mountain reservoirs that provide water to the city of Bogotá (Colombia). Our objective was to identify the environmental factors controlling the biomass and composition of algal communities in four tropical high-mountain reservoirs. We hypothesised that hydraulic dynamics is the major determining factor in temporal changes in phytoplankton communities in tropical mountain reservoirs regardless of the nutrient concentration in the system. We studied the temporal changes in phytoplankton over five years in four reservoirs that exhibit different nutrient concentrations and hydraulic management regimes. The phytoplankton in all of the reservoirs were characterised by the dominance of Dinophyceae. Canonical correspondence analyses and Pearson's correlations showed that the water renewal rate primarily explains the phytoplankton composition, followed by total nitrogen, total phosphorous and silicates. The effect of the water renewal rate was different depending on the particular conditions in each system; thus, in reservoirs with greater hydraulic dynamics, the water renewal rate explained the selection of secondary species and dominant species adapted to a broad range of environmental conditions. In the reservoir with a higher physical stability, eventual changes in the water renewal rate shifted the dominant species, reduced diversity and altered phytoplankton succession. In the reservoir with the largest volume and lowest nutrient concentration, phytoplankton species were selected primarily based on chemical and physical variables related to climatic seasonality. Our results suggest that the model for hydraulic management of the reservoirs plays an important role: in highly dynamic reservoirs, there is a direct causal relationship between phytoplankton and physical variables such as stability and water renewal rate; in less dynamic environments, phytoplankton species growth responds primarily to water chemistry.
\end{abstract}

Key words: Diversity, phytoplankton composition, thermal stability, water renewal rate.

\section{RESUMEN}

\section{Factores que controlan el fitoplancton en embalses tropicales de alta montaña destinados al consumo humano}

La dinámica hidráulica es uno de los principales factores que determinan la estructura y los cambios temporales de las comunidades fitoplanctónicas en embalses. Información de los factores que explican los cambios temporales de las comunidades biológicas en los embalses de alta montaña que proveen de agua la ciudad de Bogotá es escasa. El objetivo de este trabajo fue identificar los factores ambientales que controlan la biomasa y la composición de las comunidades algales en cuatro embalses tropicales de alta montaña. La hipótesis de trabajo fue que la dinámica hidráulica es el factor que principalmente determina los cambios temporales en la comunidad fitoplanctónica, con respecto a la concentración de nutrientes del sistema. Durante cinco años se estudiaron los cambios temporales del fitoplancton en cuatro embalses que se caracterizan por presentar diferentes concentraciones de nutrientes y diferente manejo hidráulico. El fitoplancton de todos los embalses se caracterizó por la dominancia de Dinophyceae. Análisis de Correspondencia Canónica y correlaciones de 
Pearson mostraron que la tasa de renovación hídrica explicó primariamente el fitoplancton seguida por el nitrógeno total, el fósforo total y los silicatos. El efecto de la tasa de renovación hídrica sobre el fitoplancton fue diferente dependiendo de las condiciones particulares de cada sistema; así, en embalses con una alta dinámica hidráulica, la tasa de renovación explicó las especies secundarias y seleccionó especies dominantes adaptadas a un amplio rango de condiciones ambientales. En el embalse con alta estabilidad física, cambios eventuales en la tasa de renovación cambiaron las especies dominantes, redujeron la diversidad y modificaron la sucesión del fitoplancton. En el embalse de mayor volumen y más baja concentración de nutrientes, el fitoplancton es seleccionado principalmente por otras variables físicas y químicas relacionadas con la estacionalidad climática. Los resultados sugieren que el modelo de manejo hidráulico de los embalses juega un papel importante en embalses más dinámicos, al determinar una relación causal directa entre el fitoplancton y variables físicas como la estabilidad y la tasa de renovación hídrica, mientras en embalses menos dinámicos, el crecimiento de las especies respondió principalmente a la química del agua.

Palabras clave: Diversidad, composición del fitoplancton, estabilidad térmica, tasa de renovación del agua.

\section{INTRODUCTION}

Compositional and temporal changes in phytoplankton communities are explained by complex interactions among physical, chemical, and biological factors (Margalef, 1983; Pannard et al., 2008; Padisak et al., 2010). The effects of chemical parameters on phytoplankton have been widely studied, and a smaller number of studies have considered the role of physical environmental factors in algal communities (Zohary et al., 2010). Factors such as light availability and the physical stability of the water column may be determinants for the selection of phytoplankton species in natural systems that are exposed to high hydraulic variability or in man-made lakes with intensive management (Bouvy et al., 2003; Naselli-Flores \& Barone, 2005; Tolotti et al., 2010).

The physical factors of the environment related to the thermal stability of the water column are important in determining the size and shape of phytoplankton (Naselli-Flores et al., 2007). Physical variables such as water column stability affect the phytoplankton directly by selecting shapes depending on the intensity of the turbulence and indirectly by modifying nutrient availability (Becker et al., 2008). Interactions among these factors causes a response in the algal community by selecting species according to the $\mathrm{C}$ S-R primary adaptive strategies (Reynolds, 1984; Reynolds, 1997). C-species dominate in stratified waters with high nutrient concentrations, S-species dominate in oligotrophic environments and are able to self-regulate vertical movement, and Rspecies are either tolerant of or dependent on turbulence and prefer high nutrient concentrations.

Consequently, the phytoplankton community of a lake or reservoir will be dominated by functional groups of organisms with adaptations to the environmental conditions of the ecosystem (Borges et al., 2008; Pacheco et al., 2010). Variables related to hydraulic management, such as variation in the water level, the water renewal rate, and the water discharge frequency, have important consequences for the organisation of algal communities in man-made lakes (Mac Donagh et al., 2009; Seeligmann \& Tracanna, 2009; Gaytan-Herrera et al., 2011).

Tropical aquatic systems generally have a constant temperature during the entire year, with a monomictic thermal regime and a long period of stratification in deep water bodies (Lewis, 2000). Constant temperatures and more incident radiation favour rapid stratification after holomixis (Lewis, 1973), with the subsequent development of an algal succession that frequently culminates in domination by a few species for long periods of time (Soares et al., 2009). Factors that reduce the thermal stability of the water column, such as wind and increases in the water renewal rate, may provoke changes in the system's physical and chemical conditions and thus modify the community structure (Chellappa et al., 2009). These aspects have 
been widely studied in tropical lowland water bodies (Gomes \& Miranda, 2001; Bouvy et al., 2003; Gaytan-Herrera et al., 2011), but studies in tropical mountain areas are scarce.

Our objective was to identify the environmental factors controlling the biomass and composition of algal communities in these tropical high-mountain reservoirs. Understanding the responses of algal communities to the physical and chemical characteristics of these environments will provide basic information for decision-making on issues related to reservoir operation and management. Mountainous aquatic systems in Colombia are of great importance because $70 \%$ of the population lives in the Andean area and depends primarily on the water supply from high-mountain areas; hence, reservoirs such as those supplying water to the city of Bogotá have been constructed to ensure adequate coverage of the people's needs. We hypothesised that hydrological dynamics are the major determining factor in temporal changes in the phytoplankton communities of tropical mountain reservoirs, regardless of the nutrient concentration in the system.

\section{MATERIALS AND METHODS}

\section{Study area}

The present study was conducted as part of the monitoring that the Empresa de Acueducto $y$ Alcantarillado de Bogotá E.S.P. (Aqueduct and Sewage Company of Bogotá) is currently performing in the reservoirs that provide drinking water to Bogotá (Fig. 1). Bogotá is located in the Eastern Cordillera of Colombia at 2600 m.a.s.1. and has a population surpassing eight million inhabitants. To meet the daily water demand, the city is provided with water from the Chuza, San Rafael, La Regadera, and Chisacá reservoirs in addition to water from several nearby streams.

The studied reservoirs exhibit differences in bathymetry, reservoir volumes and nutrient concentrations (Table 1). Chisacá, La Regadera, and San Rafael have annual rainfalls varying from 900 to $1200 \mathrm{~mm}$ and two rainy seasons, one from April-June and another from SeptemberNovember. Chuza has an annual rainfall near $3000 \mathrm{~mm}$ with a single but prolonged rainy season from May to August. Overall, the basins

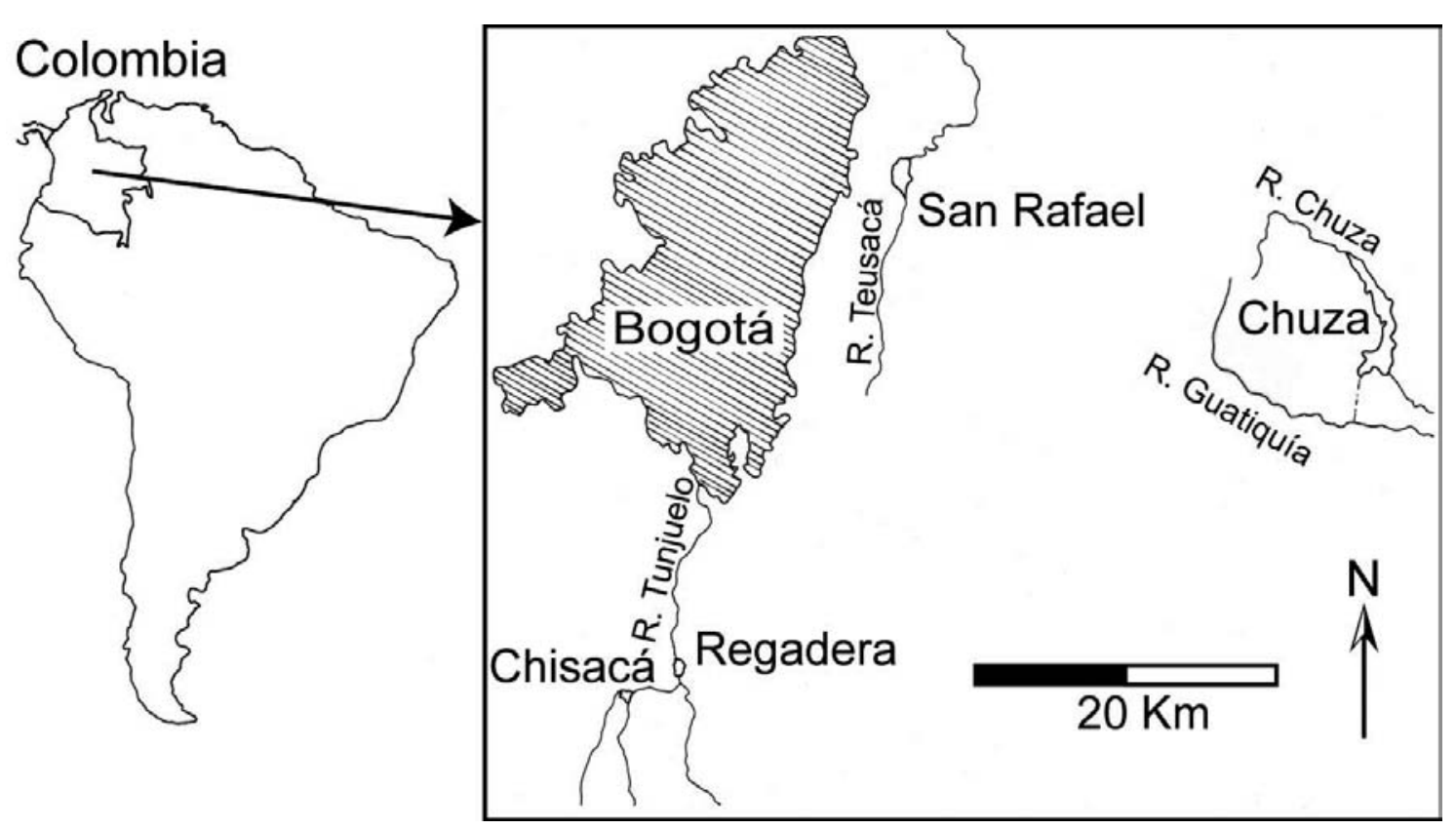

Figure 1. Geographic locations of the four reservoirs studied. Ubicación geográfica de los cuatro embalses estudiados. 
of all of the reservoirs flow in areas with highly organic and deep soils and benefit from different levels of protection. The Chuza basin lies within a national natural park with dominant herbaceous and shrubby vegetation typical of páramo ecosystems. The Chisacá, La Regadera and San
Rafael basins are poorly protected with extensive crop fields and human settlements nearby.

The detection of a two-month period with a high density of Dolichospermum solitarium (Klebahn) Wacklin, Hoffmann \& Komárek (formerly Anabaena solitaria Klebahn) in La Regadera at

Table 1. Summary of the geographic and morphometric data and median values of the physical and chemical characteristics studied in the four reservoirs. Data within brackets indicate the range of values. Resumen de las características geográficas y morfométrica y mediana de las variables físicas y químicas estudiadas. Valores en paréntesis indican el rango de la variable.

\begin{tabular}{|c|c|c|c|c|}
\hline & Chisacá & La Regadera & San Rafael & Chuza \\
\hline Coordinates & $\begin{array}{l}4^{\circ} 23^{\prime} 47.7^{\prime \prime} \mathrm{N} \\
74^{\circ} 8^{\prime} 32.4^{\prime \prime} \mathrm{W}\end{array}$ & $\begin{array}{c}4^{\circ} 23^{\prime} 4.9^{\prime \prime} \mathrm{N} \\
74^{\circ} 10^{\prime} 11.9^{\prime \prime} \mathrm{W}\end{array}$ & $\begin{array}{c}4^{\circ} 42^{\prime} 10.2^{\prime \prime} \mathrm{N} \\
73^{\circ} 59^{\prime} 14.6^{\prime \prime} \mathrm{W}\end{array}$ & $\begin{array}{c}4^{\circ} 34^{\prime} 22.7^{\prime \prime} \mathrm{N} \\
73^{\circ} 42^{\prime} 16.8^{\prime \prime} \mathrm{W}\end{array}$ \\
\hline Altitude (m.a.s.l.) & 3146 & 2997 & 2777 & 2990 \\
\hline Maximum volume $\left(\mathrm{m}^{3}\right)$ & 7072183 & 4000000 & 50000000 & 250000000 \\
\hline Area (ha) & 53 & 41 & 371 & 580 \\
\hline Maximum depth (m) & 24 & 26 & 50 & 85 \\
\hline Relative depth (\%) & 2.9 & 3.6 & 2.3 & 3.1 \\
\hline Water renewal rate $\left(\mathrm{d}^{-1}\right)$ & $\begin{array}{c}0.009 \\
(0-0.061)\end{array}$ & $\begin{array}{c}0.042 \\
(0-0.25)\end{array}$ & $\begin{array}{c}0.002 \\
(0.003-0.024)\end{array}$ & $\begin{array}{c}0.007 \\
(0.001-0.015)\end{array}$ \\
\hline Conductivity $(\mu \mathrm{S} / \mathrm{cm})$ & $\begin{array}{c}27.0 \\
(10-38)\end{array}$ & $\begin{array}{c}24.0 \\
(11-61.5)\end{array}$ & $\begin{array}{c}58.0 \\
(6-89)\end{array}$ & $\begin{array}{c}33.4 \\
(5-49)\end{array}$ \\
\hline Total organic carbon $(\mu \mathrm{g} / \mathrm{l})$ & $\begin{array}{c}4700 \\
(2500-10700)\end{array}$ & $\begin{array}{c}4800 \\
(2300-11200)\end{array}$ & $\begin{array}{c}3600 \\
(600-113600)\end{array}$ & $\begin{array}{c}2600 \\
(250-10300)\end{array}$ \\
\hline Total phosphorus $(\mu \mathrm{g} / \mathrm{l})$ & $\begin{array}{c}40 \\
(<10-2140)\end{array}$ & $\begin{array}{c}70 \\
(<10-750)\end{array}$ & $\begin{array}{c}20 \\
(<10-1330)\end{array}$ & $\begin{array}{c}20 \\
(<10-2190)\end{array}$ \\
\hline Total Kjedahl nitrogen $(\mu \mathrm{g} / \mathrm{l})$ & $\begin{array}{c}700 \\
(<100-3800)\end{array}$ & $\begin{array}{c}700 \\
(<100-3000)\end{array}$ & $\begin{array}{c}600 \\
(<100-12000)\end{array}$ & $\begin{array}{c}400 \\
(<100-3800)\end{array}$ \\
\hline Soluble reactive phosphorus SRP $(\mu \mathrm{g} / \mathrm{l})$ & $\begin{array}{c}20 \\
(<10-1063)\end{array}$ & $\begin{array}{c}20 \\
(<10-40)\end{array}$ & $\begin{array}{c}10 \\
(<10-50)\end{array}$ & $\begin{array}{c}10 \\
(10-50)\end{array}$ \\
\hline $\mathrm{N}-\mathrm{N}_{3}^{-}(\mu \mathrm{g} / \mathrm{l})$ & $\begin{array}{c}130 \\
(<10-610)\end{array}$ & $\begin{array}{c}170 \\
(<10-1143)\end{array}$ & $\begin{array}{c}100 \\
(<10-490)\end{array}$ & $\begin{array}{c}70 \\
(<10-350)\end{array}$ \\
\hline $\mathrm{N}-\mathrm{N}_{2}^{-}(\mu \mathrm{g} / \mathrm{l})$ & $\begin{aligned} & 3.0 \\
(< & 1.0-10)\end{aligned}$ & $\begin{aligned} & 3.0 \\
&(<1.0-10)\end{aligned}$ & $\begin{aligned} & 2.0 \\
&(<1.0-13)\end{aligned}$ & $\begin{aligned} & 2.0 \\
(< & 1.0-15)\end{aligned}$ \\
\hline $\mathrm{N}-\mathrm{NH}_{4}^{+}(\mu \mathrm{g} / \mathrm{l})$ & $\begin{array}{c}200 \\
(<100-1000)\end{array}$ & $\begin{array}{c}200 \\
(<100-700)\end{array}$ & $\begin{array}{c}200 \\
(<100-1500)\end{array}$ & $\begin{array}{c}180 \\
(<100-439)\end{array}$ \\
\hline SRSi $(\mu \mathrm{g} / \mathrm{l})$ & $\begin{array}{c}3210 \\
(673-14574)\end{array}$ & $\begin{array}{c}2980 \\
(1004-13661)\end{array}$ & $\begin{array}{c}1710 \\
(406-9929)\end{array}$ & $\begin{array}{c}1000 \\
(164-2806)\end{array}$ \\
\hline $\mathrm{pH}$ & $\begin{array}{c}6.82 \\
(5.04-8.8)\end{array}$ & $\begin{array}{c}6.90 \\
(6.02-8.75)\end{array}$ & $\begin{array}{c}7.00 \\
(6.02-7.9)\end{array}$ & $\begin{array}{c}7.34 \\
(6.1-7.87)\end{array}$ \\
\hline Total solids (mg/l) & $\begin{array}{c}42.5 \\
(10-221)\end{array}$ & $\begin{array}{c}40.0 \\
(20-135)\end{array}$ & $\begin{array}{c}46.0 \\
(4.7-115)\end{array}$ & $\begin{array}{c}28.5 \\
(14-103)\end{array}$ \\
\hline Water temperature $\left({ }^{\circ} \mathrm{C}\right)$ & $\begin{array}{c}13.2 \\
(11.1-18.7)\end{array}$ & $\begin{array}{c}14.1 \\
(11.7-18.3)\end{array}$ & $\begin{array}{c}15.3 \\
(13.5-18.7)\end{array}$ & $\begin{array}{c}13.2 \\
(11.5-17.8)\end{array}$ \\
\hline Secchi disk (m) & $\begin{array}{c}1.2 \\
(0.4-3.7)\end{array}$ & $\begin{array}{c}1.0 \\
(0.12-1.85)\end{array}$ & $\begin{array}{c}2.5 \\
(1.5-4.4)\end{array}$ & $\begin{array}{c}4.0 \\
(0.3-6.4)\end{array}$ \\
\hline Temperature gradient $\left({ }^{\circ} \mathrm{C}\right)$ & $\begin{array}{c}6.1 \\
(1.9-8.1)\end{array}$ & $\begin{array}{c}5.3 \\
(0.5-8.6)\end{array}$ & $\begin{array}{c}6.5 \\
(1.1-8.8)\end{array}$ & $\begin{array}{c}3.0 \\
(0.3-7.9)\end{array}$ \\
\hline Mixing zone (m) & $\begin{array}{c}4.0 \\
(2-14)\end{array}$ & $\begin{array}{c}3.0 \\
(1-6)\end{array}$ & $\begin{array}{c}7.5 \\
(1-30)\end{array}$ & $\begin{array}{c}8.0 \\
(1-56)\end{array}$ \\
\hline Euphotic zone: mixing zone & $\begin{array}{c}1.01 \\
(0.19-2.5)\end{array}$ & $\begin{array}{c}1.08 \\
(0.32-2.16)\end{array}$ & $\begin{array}{c}0.92 \\
(0.29-8.91)\end{array}$ & $\begin{array}{c}1.20 \\
(0.09-10.34)\end{array}$ \\
\hline
\end{tabular}


the end of 2004 highlighted the necessity of increasing the thermal instability of the lakes to prevent similar events in the future. For this reason, short and sporadic openings of the bottom valves of Chisacá and La Regadera have been conducted since mid-2005 to allow the rapid mixing of the water column. The frequency and intensity of this procedure are variable, ranging from weekly to monthly, and dependent on the water availability in the basin.

\section{Sample collection and analysis}

Samplings were performed between January 2004 and March 2009 with a frequency varying between monthly and quarterly depending on the reservoir. In the case of Chisacá and La Regadera, the monitoring of plankton and the thermal structure of the water column was performed monthly, whereas water samples for the chemical analyses were collected quarterly, both starting in mid-2005.

There was only one sampling point for each basin in Chisacá and La Regadera and four sampling points each in San Rafael and Chuza. At each of the sampling points, we collected 3-litre samples of water at half the transparency value of the Secchi disk (SD) using a van Dorn bottle. Samples were carefully homogenised, and then smaller volumes were taken for the chemical analyses and the study of phytoplankton. Samples for the analysis of phytoplankton were preserved in Lugol's solution.

Temperature and oxygen profiles were produced using a multiparameter probe (YSI 52) collecting measurements at one-meter intervals starting from the surface and moving down to the bottom. Water transparency was estimated using a Secchi disk. Conductivity and $\mathrm{pH}$ were measured in situ at every sampling point with a $\mathrm{HACH}$ probe.

The following parameters were analysed following the APHA et al. (2005) methods: alkalinity $\left(\mathrm{H}_{2} \mathrm{SO}_{4}\right.$ titration), hardness (2320-B titration), turbidity (nephelometric), silicates (SRSi, colorimetric-molybdosilicate), total phosphorus (TP, colorimetric-stannous chloride 4500-P), soluble reactive phosphorus (SRP, 4500-P), total Kjeldahl nitrogen (TKN, $\mathrm{H}_{2} \mathrm{SO}_{4}$ titration), $\mathrm{N}-$
$\mathrm{NH}_{4}^{+}\left(4500-\mathrm{NH}_{4}-\mathrm{C}\right), \mathrm{N}-\mathrm{NO}_{3}^{-}\left(4500-\mathrm{NO}_{3}-\mathrm{B}\right)$, $\mathrm{N}-\mathrm{NO}_{2}^{-}$(4500- $\left.\mathrm{NO}_{2}-\mathrm{B}\right)$, total iron (TFe, ICPlasma 3500-Fe-C), and total organic carbon (TOC, combustion-infrared 5310-B).

Phytoplankton were quantified using sedimentation chambers (Utermöhl, 1958) and by counting at least 200 individuals of the most frequent taxon under a Bausch \& Lomb inverted microscope at $800 \times$.

\section{Data analysis}

Three approaches were used to describe the physical stability of the water column: the surfacebottom temperature gradient, Schmidt's stability and the rate of water renewal for the reservoir. Schmidt's thermal stability (Wetzel \& Likens, 2000) was calculated in relation to the water column at the sampling point. The rate of water retention was analysed as the average daily values for the 15 days before the sampling.

The euphotic zone of the water column was estimated using a factor of 2.7 times the Secchi disk depth (Cole, 1994). The mixing zone $\left(z_{\text {mix }}\right)$ was estimated from the temperature and dissolved oxygen profiles (Becker et al., 2008). The ratio between the euphotic zone and the depth of the mixing layer $\left(z_{\mathrm{eu}}: z_{\mathrm{mix}}\right)$ was calculated to estimate the availability of light in the water column (Jensen et al., 1994). Data on phytoplankton were transformed to biovolume values by measuring the cells of each species and approximating them to geometric shapes (Sun \& Liu, 2003). The assignment of each species to the strategies $\mathrm{C}, \mathrm{S}$, and R was performed based on morphological traits (Reynolds, 1997).

Dissolved nutrients (SRP, N- $\mathrm{NH}_{4}^{+}, \mathrm{N}-\mathrm{NO}_{3}^{-}$ and $\mathrm{N}-\mathrm{NO}_{2}^{-}$) represented a high percentage of data that fell below the detection limit of the analytical methods used in our study but maintained the same tendencies observed for TP and TKN. We found that TP was significantly correlated to SRP $(r=0.89, p<0.001, n=65)$ and NKT to $\mathrm{N}-\mathrm{NH} 44^{+}(r=0.37, p<0.001, n=70)$ and DIN $(r=0.32, p<0.001, n=82)$. Therefore, we used NKT and TP in the statistical analyses to understand the relationships between phytoplankton and nutrients. NTK and TP data below 
the detection limit ( $<5 \%$ of data) were estimated as an average between zero and the value of the detection limit in the statistical analyses.

The relationship between phytoplankton and the environment was analysed with a canonical correspondence analysis-CCA (Jongman et al., 1995). Data from Chisacá and La Regadera were analysed together due to the low number of samples of chemical data and the connectivity between the two basins.

First, data were analysed with a CCA with the forward selection (full model) procedure, including physical, chemical and hydrological variables that showed a low correlation coefficient (inflation $<10 \%$ ). In the final CCA (minimum model), we excluded non-significant variables, as well as species with a low biovolume and a frequency lower than $5 \%$ of the total sample. A Monte Carlo test (999 permutations, $\alpha=0.05$ ) was used to find the significance of the axes of species and of the relationship between species and environment.

A CCA was used to find the species that are more strongly related to the environmental variables and the species in which the more significant environmental variables were added one by one. Species accounting for more than $10 \%$ of the variance in each variable were considered to be selected by this variable.

With the aim of analysing changes in the structure of phytoplankton communities, we calculated Pearson's correlations between the main environmental variables and the ecological diversity (species richness and Shannon index) and community turnover rate. The community turnover rate per sample was calculated from the Shannon beta diversity according to Jost (2007).

\section{RESULTS}

\section{Physical and chemical characteristics of the reservoirs}

The four reservoirs showed a tendency for thermal stratification during most of the year and presented a temperature gradient between the surface and bottom that was always less than $7{ }^{\circ} \mathrm{C}$ (Fig. 2). Thermal stratification induced a strong chemical gradient in the water column that is reflected in the hypoxic conditions of the hypolimnion. In Chisacá and La Regadera, the low water renewal rate in 2004 caused the maintenance of a thermally and chemically stratified water column for 17 months (Fig. 3). Afterwards, more intense hydraulic management caused strong stratifications lasting for short periods of time (less than 5 months) and deep mixed layers lasting for prolonged periods of time. The high variation in the water renewal rate determined the high variability in the thermal stability of the two reservoirs, resulting in periods with more stability during the dry seasons.

In San Rafael, there was also a thermal and chemical stratification during three consecutive years (2006 to 2008) caused by a low water renewal rate. Periods with low thermal stability in the water column were caused by decreases in water retention in the reservoir. Chuza presented a thermal stratification regime that is driven by climate seasonality, in which the rainy seasons and high wind speeds drive the partial mixing of the water column and the dry seasons cause a thermal stratification that lasts seven months.

The ratio $z_{\mathrm{eu}}: z_{\text {mix }}$ exhibited a median $>1$ in Chisacá, La Regadera and Chuza. The four reservoirs tended to have higher values of $z_{\mathrm{eu}}: z_{\text {mix }}$ when a period of low thermal stability changed to a high relative stability period. La Regadera presented values $<1$ before the intensification of the hydraulic management of the reservoir, whereas in Chisacá, no temporal pattern was detected. During the period of prolonged stratification, San Rafael presented values that were almost always $<1$ with a lower degree of variability, suggesting light limitations for phytoplankton growth. Chuza showed variation in the ratio values that was related to climatic seasonality (Fig. 3; Table 1).

All of the reservoirs exhibited chemical stratification, with high nutrient values in the hypolimnion. There were chemical differences among the reservoirs: Chisacá and La Regadera showed the highest TP and TKN concentrations and the lowest Secchi disk values; San Rafael presented the lowest TP concentrations; and Chuza showed the lowest TKN concentration 




Figure 2. Temporal behaviour of water temperature and oxygen in the Chisacá, La Regadera, San Rafael, and Chuza reservoirs. The striped area represents the water column depth. Comportamiento temporal de la temperatura y el oxígeno del agua en los embalses Chisacá, La Regadera, San Rafael y Chuza. El área reticulada representa la profundidad de la columna de agua.

and the highest Secchi disk values (Table 1). The chemical characteristics of the reservoirs showed complex variations on a temporal basis that were not directly explained by the hydrological climatic seasonality; however, the chemical characteristics indicate that during the stratification periods, Chisacá, La Regadera and San Rafael tended to present higher concentrations of TKN, TP and TOC.

\section{Temporal patterns of phytoplankton}

Algal biovolumes in the different reservoirs were consistent with the nutrient concentrations. In 

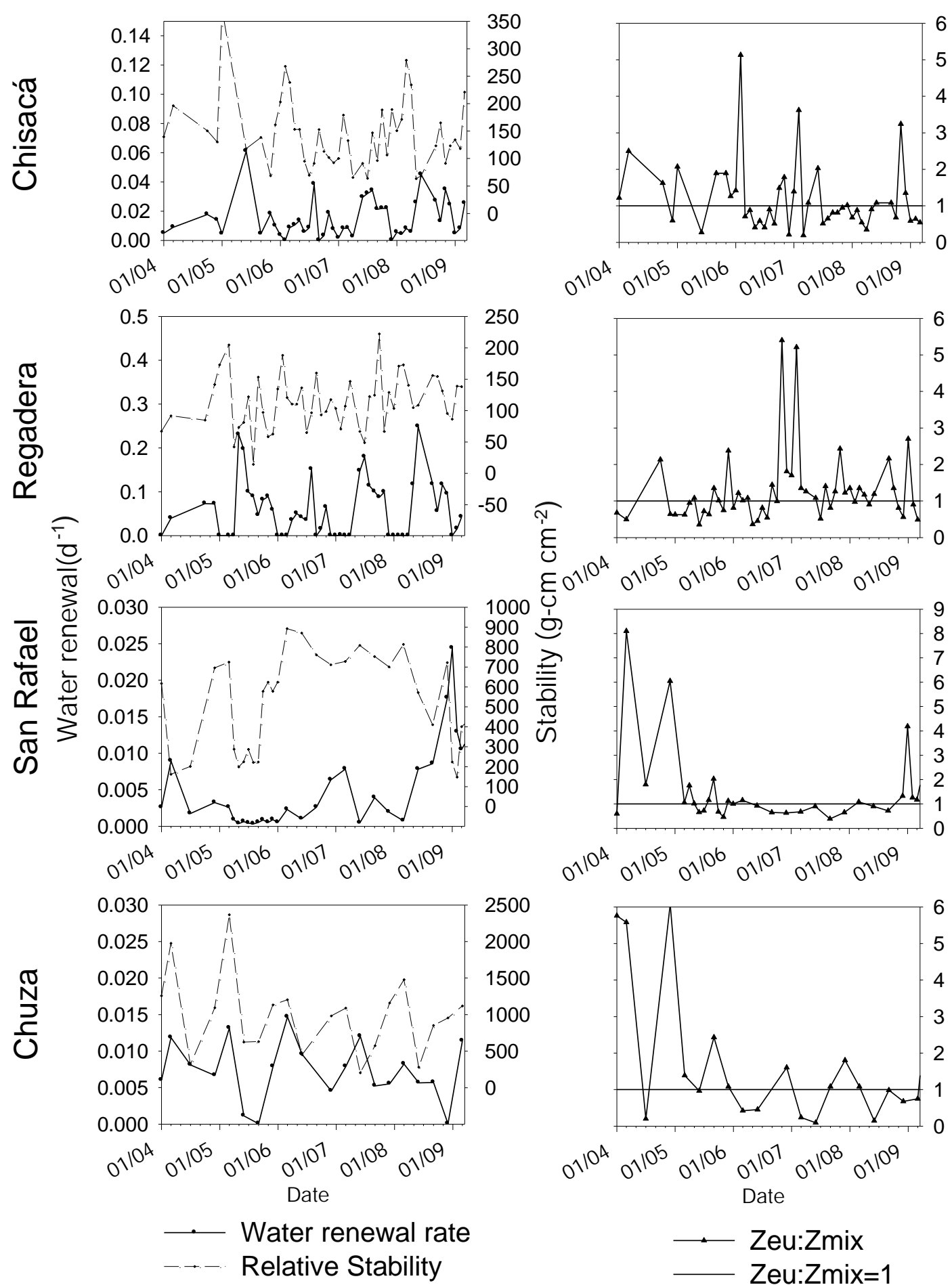

$$
\begin{aligned}
0^{110^{4}} \text { o } 110^{5} \text { o } 111^{6} \text { o } 110^{7} \text { o } 110^{8} \text { o } 110^{9} \\
\text { Date } \\
\longrightarrow \text { Zeu:Zmix } \\
\longrightarrow \text { Zeu:Zmix=1 }
\end{aligned}
$$

Figure 3. Temporal variation of the water renewal rate, Schmidt's thermal stability and the $z_{\mathrm{eu}}: z_{\text {mix }}$ ratio. Notice that the axis scales are different. Variación temporal de la tasa de renovación del agua, la estabilidad térmica de Schmidt y la relación $\mathrm{z}_{e u}: \mathrm{z}_{m i x}$. Note que las escalas de los ejes son diferentes para cada embalse. 
this way, the highest values were found in La Regadera $\left(\right.$ mean $\left.=13 \mathrm{~mm}^{3} / 1\right)$ and Chisacá $\left(\right.$ mean $\left.=16 \mathrm{~mm}^{3} / 1\right)$, whereas Chuza presented the lowest values $\left(<7 \mathrm{~mm}^{3} / \mathrm{l}\right)$. Algae communities were different in every reservoir, but overall, there was more similarity between the communities of Chisacá and La Regadera, and between those of San Rafael and Chuza (Fig. 4). Dinophyceae was the group with more dominant species, and Desmidiaceae (Zygnemaphyceae) was the family with the highest diversification of species in all of the reservoirs.

During 2004, Chisacá presented a community dominated by Peridinium cf. cinctum, Ceratium cf. hirundinella and Trachelomonas volvocina. With the increase in hydraulic management activities in the reservoir since mid-2005, there was a period dominated by $P$. cinctum. During the stratification period at the beginning of 2006 , there was a change in the community that resulted in a phase dominated by $C$. hirundinella. This pattern was maintained during the periods of mixing and stratification in 2007. During most of 2008, C. hirundinella comprised more than $80 \%$ of the biovolume. In this reservoir, the algal community underwent prolonged periods with one dominant species.

La Regadera showed high variation in community structure, which varied between $C$. $h i$ -
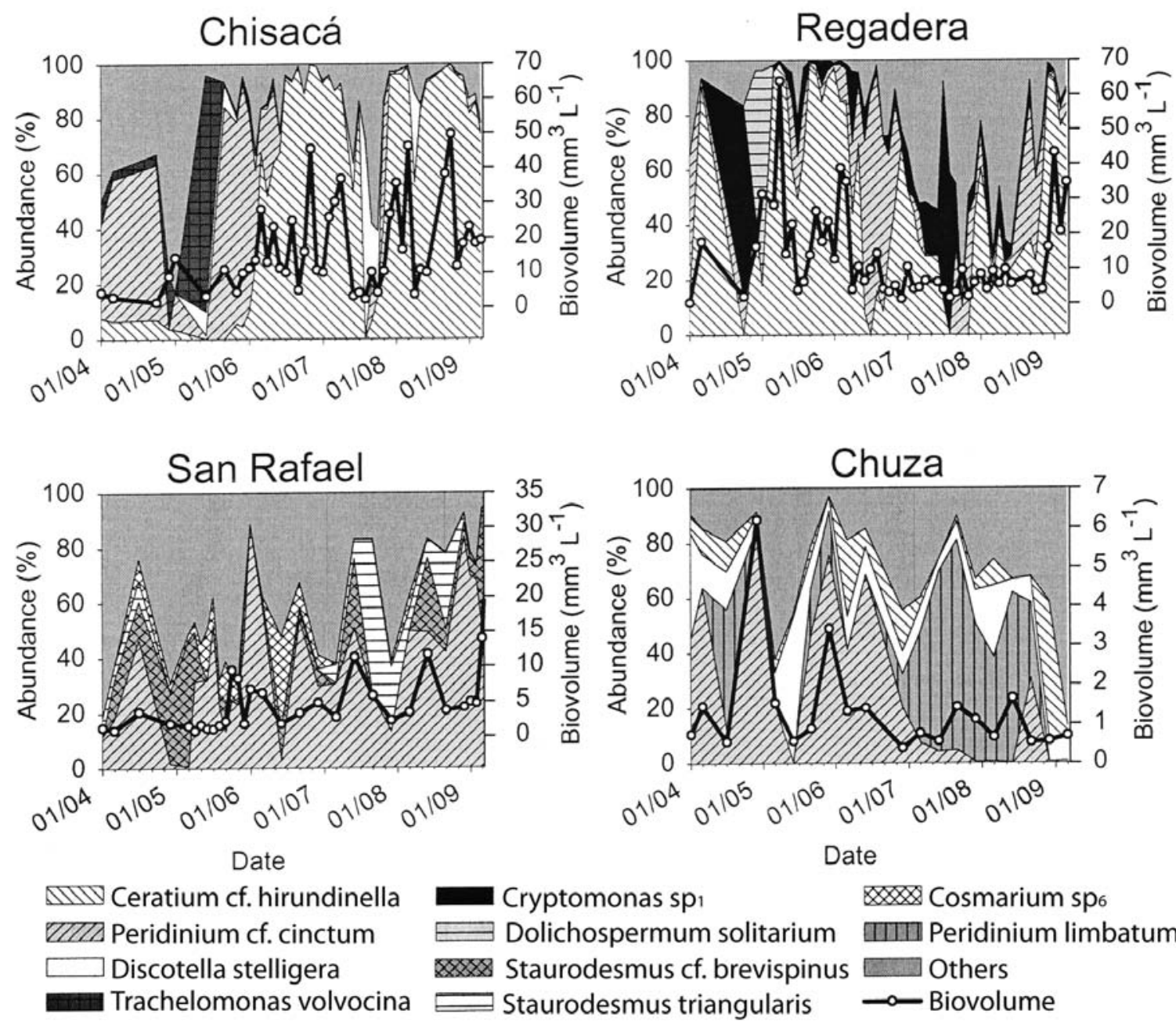

Cryptomonas sp

Cosmarium sp6

IIIII) Peridinium limbatum

$\square$ Discotella stelligera

rodesmus cf. brevispinus

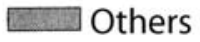

$\rightarrow$ Biovolume

Figure 4. Temporal behaviour of the dominant phytoplankton species in the four reservoirs studied. Comportamiento temporal de las especies de fitoplancton dominantes en los cuatro embalses estudiados. 
rundinella, Cryptomonas $\mathrm{sp}_{1}$, and $P$. cinctum as the dominant species. At the end of 2004, there was a bloom of Dolichospermum solitarium (>20 000 cells $/ \mathrm{ml}$ ) followed by the rapid growth of $C$. hirundinella. During most of 2006, the basin was dominated by $C$. hirundinella.

San Rafael revealed a more diverse community in which $C$. hirundinella was the species with the largest biovolume, but this community had a high variation in the dominant species and sporadic events with three or fewer species accounting for $80 \%$ of the biovolume. During the two prolonged periods of stratification, small(Staurodesmus triangularis and Cosmarium sp.6) and medium-sized (Staurodesmus cf. brevispinus) Desmidiaceae species were dominant or codominant. In Chuza, there was a reduced algal biovolume with dominance shifting from one species to another among P. cinctum, Discotella stelligera, Peridinium limbatum, and C. hirundinella.

The CCA models significantly explained $13.3 \%$ of Chisacá and La Regadera species variabil- ity, $17.3 \%$ of San Rafael species variability and $12.5 \%$ of Chuza species variability (Table 2). The water renewal rate significantly explained the temporal variation in the phytoplankton communities in all of the reservoirs, with a higher fraction of variance explained for Chisacá, La Regadera and San Rafael (Fig. 5).

The CCA model for Chisacá and La Regadera suggests an inverse relationship between the water renewal rate and the temperature, explaining most of the temporal variability in phytoplankton; $\mathrm{TP}$ and $\mathrm{TFe}$ explained a second gradient of phytoplankton species variability. The CCA model for San Rafael shows that the phytoplankton species variability was accounted for TOC, water renewal rate, $\mathrm{SRSi}$, and the ratio $z_{\mathrm{eu}}: z_{\text {mix }}$. According to the CCA model for Chuza, TKN, $\mathrm{SRSi}, \mathrm{pH}$, and SD were the most important variables for phytoplankton.

The CCA models suggest that periods with low and intermediate water renewal rates in Chisacá and La Regadera selected some species

Table 2. Summary of the canonical correspondence analyses and the variances of species explained by the environmental variables. Resumen de los Análisis de Correspondencia Canónica y varianza explicada por las variables ambientales.

\begin{tabular}{|c|c|c|c|c|c|c|c|c|}
\hline \multicolumn{3}{|c|}{$\begin{array}{l}\text { Chisacá and La Regadera } \\
\qquad(n=46)\end{array}$} & \multicolumn{3}{|c|}{$\begin{array}{l}\text { San Rafael } \\
(n=84)\end{array}$} & \multicolumn{3}{|c|}{$\begin{array}{l}\text { Chuza } \\
(n=78)\end{array}$} \\
\hline \multicolumn{2}{|l|}{$\lambda$ first 3 axes } & 0.21 & $\lambda$ first $3 \mathrm{a}$ & & 0.20 & $\lambda$ first $3 \mathrm{a}$ & & 0.17 \\
\hline \multicolumn{2}{|l|}{ Total $\lambda$} & 1.55 & Total $\lambda$ & & 1.14 & Total $\lambda$ & & 1.39 \\
\hline \multicolumn{2}{|c|}{ Variance species data 3 axes (\%): } & 13.3 & Variance & ta 3 axes $(\%)$ : & 17.3 & Variance & xes $(\%)$ : & 12.5 \\
\hline \multicolumn{2}{|c|}{ Variance species-environment (\%): } & 62.9 & Variance & ivironment (\%): & 59.7 & Variance & vironment $(\%)$ : & 52.5 \\
\hline \multicolumn{9}{|c|}{ Conditional effects } \\
\hline Variable & $\lambda$ & $\mathrm{P}$ & Variable & $\lambda$ & $\mathrm{P}$ & Variable & $\lambda$ & $\mathrm{P}$ \\
\hline W_Ren & 0.07 & 0.008 & W_Ren & 0.05 & 0.001 & TKN & 0.05 & 0.001 \\
\hline $\mathrm{TP}$ & 0.06 & 0.005 & TOC & 0.05 & 0.001 & SRSi & 0.04 & 0.001 \\
\hline $\mathrm{TFe}$ & 0.05 & 0.022 & SRSi & 0.04 & 0.001 & $\mathrm{pH}$ & 0.04 & 0.001 \\
\hline Turb & 0.05 & 0.019 & EufMix & 0.04 & 0.001 & SD & 0.04 & 0.001 \\
\hline TKN & 0.05 & 0.048 & TKN & 0.03 & 0.001 & Temp & 0.03 & 0.001 \\
\hline \multirow[t]{6}{*}{ Temp } & 0.05 & 0.036 & MixZon & 0.03 & 0.001 & Stab & 0.03 & 0.006 \\
\hline & & & SD & 0.02 & 0.001 & W_Ren & 0.03 & 0.008 \\
\hline & & & Alca & 0.02 & 0.005 & Hardn & 0.02 & 0.01 \\
\hline & & & TemGra & 0.02 & 0.012 & $\mathrm{TP}$ & 0.03 & 0.02 \\
\hline & & & Hardn & 0.01 & 0.027 & TOC & 0.02 & 0.043 \\
\hline & & & $\mathrm{TFe}$ & 0.02 & 0.043 & & & \\
\hline
\end{tabular}

$\lambda$ : Eigenvalue, P: p-value, W_Ren: Water renewal rate, TP: Total phosphorus, TFe: Total Iron, Turb: Turbidity, TKN: Total Kjedahl nitrogen, Temp: Temperature, TOC: Total organic carbon, SRSi: Reactive Silica, EufMix: $z_{\mathrm{eu}}: z_{\mathrm{mix}}$, MixZon: Mixing zone, SD: Secchi disk, Alca: Alkalinity, TemGra: Gradient of temperature, Hardn: Hardness, Stab: thermal Stability. 
of Desmidiaceae (Staurodesmus dejectus, Staurodesmus cf. brevispinus, Staurastrum $\mathrm{sp}_{.1}$, Staurastrum cf. limneticum, Staurodesmus $\mathrm{sp}_{.6}$ ) and Chlorophyceae (Scenedesmus spp.) with small and medium sizes and $\mathrm{C}$ strategies (Reynolds, 1997). Low and intermediate values of phosphorus selected for the colonial species Sphaerocystis cf. schroeteri, Dinobryon divergens, and Eudorina elegans, whereas high values selected for Staurodesmus cf. brevispinus. In San Rafael, high rates of water renewal selected Gymnodinium $\mathrm{sp}_{\cdot 2}$, intermediate rates accounted
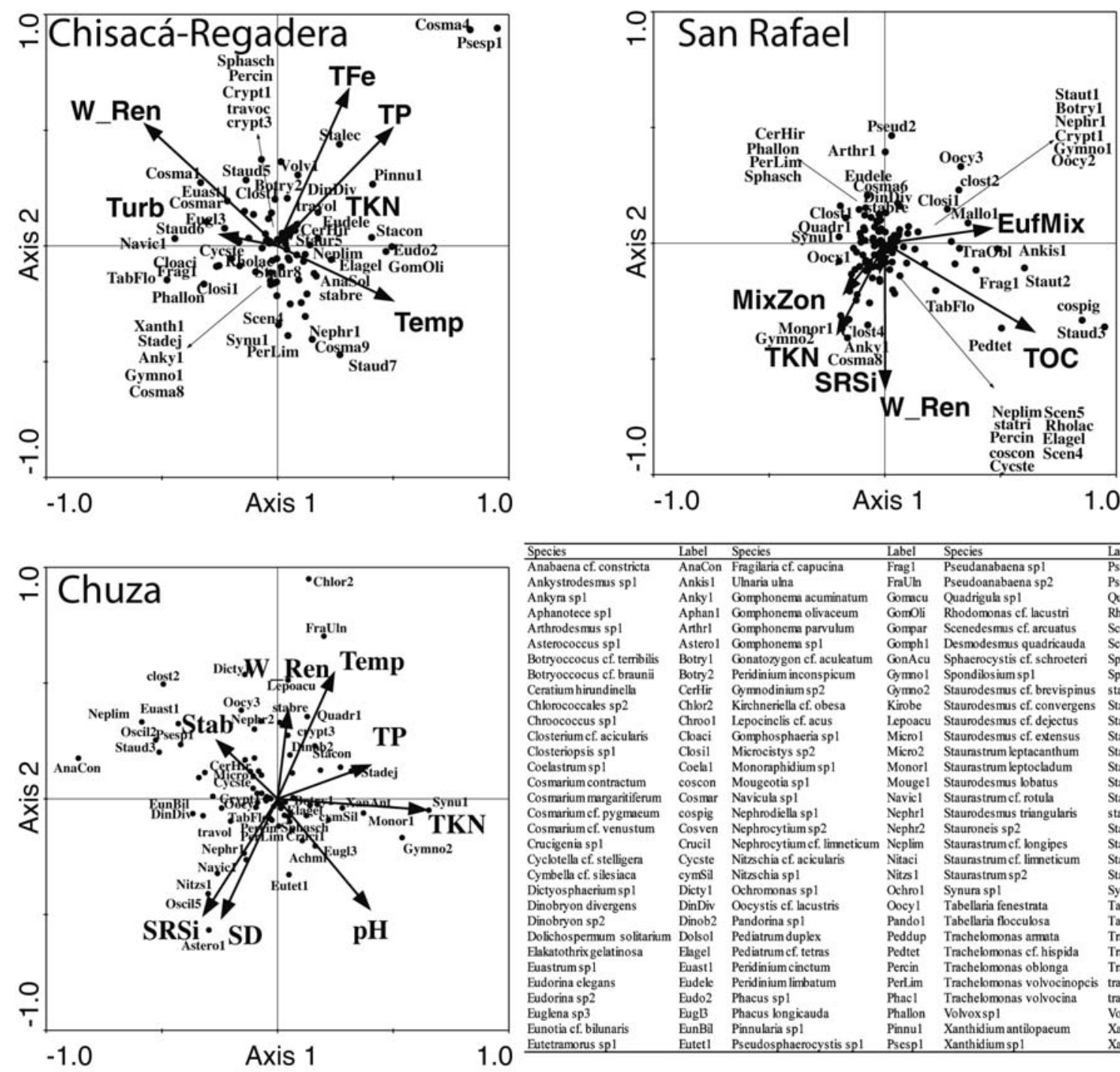

\begin{tabular}{|c|c|c|c|c|c|}
\hline Species & Label & Species & Label & Species & Label \\
\hline Anabaena cf. constricta & AnaCon & Fragilaria cf. capucina & Frag1 & Pseudanabaena spl & Pseudl \\
\hline Ankystrodesmus sp 1 & Ankis1 & Ulnaria uha & FraUlh & Pseudoanabaena sp2 & Pseud2 \\
\hline Ankyra spl & Anky1 & Gomphonem acuminatum & Gomncu & Quadriguh sp1 & Quadr1 \\
\hline Aphanotece sp1 & Aphan I & Gomphonem olivaceum & GomOli & Rhodomonas ef. lacustri & Rholac \\
\hline Arthrodesmus spl & Arthrl & Gomphonema parvulum & Gompar & Scenedesmus cf. arcuatus & Scede3 \\
\hline Asterococcus spl & Asterol & Gomphonem sp1 & Gomphl & Desmodesmus quadricauda & Scequa \\
\hline Botryoccocus cf. temibilis & Botry 1 & Gonatozygon ef. aculeatum & GonAcu & Sphacrocystis cf. schroeteri & Sphasch \\
\hline Botryoccocus ef. braunï & Botry 2 & Peridinium inconspicum & Gymnol & Spondibsium sp1 & Spondl \\
\hline Ceratium hirundinellh & Cerflir & Gymodinium sp2 & Gymno2 & Staurodesmus cf. brevispinus & stabre \\
\hline Chlorococcales sp2 & Chlor2 & Kirchneriella ef. obesa & Kirobe & Staurodesmus of. convergens & Stacon \\
\hline Chroococcus spl 1 & Chrool & Lepocinclis ef. acus & Lepoacu & Staurodesmus cf, dejectus & Stadej \\
\hline Closterium ef. acicularis & Cloaci & Gomphosphaeria sp1 & Microl & Staurodesmus ef. extensus & StaExt \\
\hline Closteriopsis sp1 1 & Closil & Microcistys sp2 & Micro2 & Staurastrum leptacanthum & Stakec \\
\hline Coelastrum sp1 & Coela1 & Monoraphidium sp 1 & Monorl & Staurastrum leptocladum & Stalep \\
\hline Cosmarium contractum & coscon & Mougeotia sp 1 & Mougel & Staurodesmus bbatus & Stalob \\
\hline Cosmarium marganitiferum & Cosmar & Navicula spi & Navicl & Staurastrum ef. rotula & Starot \\
\hline Cosmariumef. pygmeum & cospig & Neph & Nephr1 & is triangularis & statri \\
\hline Cosmarium ef. venustum & Cosven & Nephrocytium sp2 & Nephr2 & Stauroneis sp2 & Staur2 \\
\hline Crucigenia spl & Crucil & tium ef. limneticum & Neplim & ef. bn & Staur5 \\
\hline Cyclotella ef. stelligera & Cyeste & Nitzschia ef, acicularis & Nitaci & Staurastrumef. limneticum & Staut1 \\
\hline Cymbella cf. silesiaca & cymSi & Nitzschia spl 1 & Nitzs 1 & um sp2 2 & Staut2 \\
\hline Dictyosphaerium sp1 & Dicty 1 & Ochromonas sp 1 & Oehrol & Synura sp1 1 & Synul \\
\hline Dinobryon divergens & DinDiv & cf. lacustris & Oocyl & Tabell: & TabFen \\
\hline Dinobryon sp2 & Dinob2 & Pandorina sp 1 & Pandol & Tabellaria flocculosa & TabFlo \\
\hline Dolichospermum solitarium & Dolsol & Pediatrum duplex & Peddup & Trachelomonas armata & TraAm \\
\hline Elakatothrix gelatinosa & Elagel & Pediatrum ef. tetras & Pedtet & Trachelomonas ef. hispida & Trahis \\
\hline Euastrum sp1 & Euast1 & Penidinium einctum & Percin & Trachelomonas oblonga & TraObl \\
\hline Eudorina elegans & Eudek & Peridinium limbatum & Perlim & Trachelomonas volvocinopcis & travoc \\
\hline Eudorina sp2 & Eudo2 & Phacus sp1 & Phacl & Trachelomonas volvocina & travol \\
\hline Euglena sp 3 & EugB & Phacus bongicauda & Phallon & Volvoxsp1 & Volv1 \\
\hline Eunotia ef. bilunaris & EunBa & Pinnularia sp1 & Pinnul & Xanthidium antilopaeum & XanAnt \\
\hline Eutetramons spl & Eutetl & Pseudosphacrocystis sp1 & Psespl 1 & Xanthidium spl 1 & Xanth1 \\
\hline
\end{tabular}

Figure 5. Representation of the first and second axes of the canonical correspondence analyses for the studied reservoirs (Environmental variables plotted with $\lambda>0.03$ ). Labels of the representative species are shown in the figure. Label abbreviations of other species correspond to Clost: Closterium, Cosma: Cosmarium, Crypt: Crytomonas, Oocy: Oocystis, Mallo: Mallomonas, Oscil: Oscillatoria, Scene: Desmodesmus, Staud: Staurodesmus, and Stau: Staurastrum. Variable abbreviations are shown in Table 2. Representación del primer y segundo eje de los Análisis de Correspondencia Canónica realizados para los embalses estudiados (se dibujan las variables ambientales con $\lambda>0.03$ ). Los rótulos de las especies representativas se presentan en la figura. Rótulos de abreviaciones de otras especies son Clost: Closterium, Cosma: Cosmarium, Crypt: Crytomonas, Oocy: Oocystis, Mallo: Mallomonas, Oscil: Oscillatoria, Scene: Desmodesmus, Staud: Staurodesmus y Stau: Staurastrum. Las abreviaciones de las variables se presentan en la tabla 2. 
for S. triangularis and Closterium $\mathrm{sp}_{4}$, and higher rates selected Cosmarium sp.8. TOC selected additional species, whereas intermediate values accounted for Cosmarium sp.6, Oocystis cf. lacustris, and S. schroeteri and high values selected Staurodesmus $\mathrm{sp}_{3}$, Cosmarium contractum, and Cosmarium cf. pygmaeum. Low $z_{\mathrm{eu}}: z_{\mathrm{mix}}$ ratio values accounted for Fragilaria cf. capucina, Closterium sp..$_{1}$ and $C$. hirundinella. In Chuza, low values of NTK selected Oocystis cf. lacustris and intermediate values of NTK selected Gymnodinium sp.2, Monoraphidium sp..$_{1}$ and Botryoccocus cf. terribilis. Periods with low rates of water renewal selected Elakatothrix

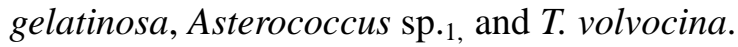

\section{Diversity and the turnover rate of phytoplankton}

Species richness and Shannon diversity index values were highly variable in all of the reservoirs and did not show any significant correlation with physical, chemical or hydraulic variables. Species richness ranged between 6 and 49, with the lowest average in Chuza (19 species) and the highest average in San Rafael (33 species). The Shannon diversity index showed the lowest value in Chisacá (0.9) and the highest value in San Rafael (1.78).

The community turnover rate presented high temporal variability in all of the reservoirs and ranged between 0.01 and 0.91. La Regadera presented the highest average (0.72) and Chisacá the lowest average (0.27). No significant correlations were found between the community turnover rate and any of the chemical and physical variables of the Chisacá and La Regadera reservoirs. The community turnover rate was significantly correlated with the water renewal rate for San Rafael $(r=-0.35, p<0.05, n=80)$ and Chuza $(r=-0.33, p<0.05, n=70)$.

\section{DISCUSSION}

Phytoplankton growth is controlled primarily by light and nutrient availability (Naselli-Flores, 2000; Becker et al., 2010). Changes in hydrology and climate can provoke the circulation of the water mass and affect the availability of light and nutrients for phytoplankton (Tundisi et al., 2008). Physical factors such as the regulation of water inflow and outflow and the water retention time in reservoirs are important factors that can drive the temporal variation of phytoplankton communities (Soares et al., 2008; Mac Donagh et al., 2009).

In this sense, our results show a higher determination of the physical factors with respect to the water chemistry and phytoplankton composition of the studied reservoirs. According to the CCAs, the water renewal rate was the predominant factor that explained the temporal variations in the composition of the algal communities in Chisacá, La Regadera and San Rafael. In additional to seasonal variation, systems with complex hydrological dynamics tended to exhibit frequent species replacement and colonisation episodes (Reyes et al., 2008). Hydrologic fluctuations and temporal variations in phosphorus levels in Chisacá and La Regadera provoked important changes in the secondary species in the system, whereas in San Rafael, the changes were related to the transition from a relatively short period of low thermal stability to a prolonged stratified period and, subsequently, to a final period of physical instability.

In Chuza, TKN, not the water renewal time, was the most important explanatory variable for the phytoplankton community. During some of the stratified periods in Chuza, there was an important reduction in the nitrogen concentration that may explain the great importance of this variable in the system. Chuza is a reservoir located in a protected basin, with low nutrient inputs from the basin during the rainy season. Because of this, small variations in the concentration of nitrogen may have an important impact on the temporal changes in phytoplankton.

Reservoirs with more complex hydrological dynamics presented broadly varied phytoplankton responses. In this sense, Chisacá and La Regadera, both reservoirs having a highly variable water renewal rate, exhibited phases when the relative abundances of one or two species constituted more than $80 \%$ of the total biovolume 
during the stratified and mixing periods, whereas in San Rafael and Chuza, these phases were less frequent, hence the communities were more diverse. Likewise, low nutrient concentrations in water bodies such as Chuza and San Rafael may promote the maintenance of more diverse communities (Interlandi \& Kilham, 2001) in which there is a low probability of dominance by a few species.

In the case of Chisacá and La Regadera, during the period of thermal instability there was an initial phase with low variability in algal biomass that was followed by changes of up to $100 \%$ of the biomass. Subsequently, a single species was dominant until 2006 , followed by less frequent periods in 2007 and 2008 of dominance by a few species.

Greater physical stability has consequences for phytoplankton communities by provoking algal succession, where an eventual destabilisation of the water column may act as a disturbance (Sommer et al., 1993). In San Rafael, the prolonged stratification time caused dominant species to be explained by the water renewal rate. Increases in the water renewal rate have a strong impact on the algal succession of this reservoir by reducing the equitability among species and the community turnover rate. Chisacá and La Regadera exhibited communities with a temporal succession that was not related to hydrology and was dominated by species adapted to a high degree of instability in the water column.

The smaller volume of La Regadera accounts for the higher impact of hydraulic movements on the renewal rate of this system in comparison with Chisacá. This is why $C$. hirundinella can dominate in conditions of low to moderate turbulence but not when the instability of the water column is too high. The perennial dominance of Dinophyceae species in a polymictic reservoir has been reported in subtropical reservoirs (Townsend \& Luong-Van, 1998; Townsend, 2001), suggesting that species in this group can reach a stage where they are self-maintained and resist holomixis.

The maintenance of a permanent stratification, or a low ratio $z_{\mathrm{eu}}: z_{\mathrm{mix}}$, creates conditions in which phytoplankton are limited by nutrients and light. In these circumstances, species with strategies of tolerance to stress are favoured and dominate in the community (Reynolds, 2006). Regard- less of the nutrient concentration and the thermal stability of the different reservoirs, the phytoplankton communities were dominated most of the time by Dinophyceae with $\mathrm{S}$ strategies, such as $C$. hirundinella, $P$. cinctum, and P. limbatum. C. hirundinella is a large Dinophyceae with a low growth rate that occurs preferentially in water bodies with a stable epilimnion and low nutrient concentrations (Harris, 1986; Reynolds, 1997; Kruk et al., 2010). Its capacity to regulate its depth, locate itself in zones with adequate light intensities and move to areas with higher nutrient concentrations determines its dependence on low and moderate turbulence levels (Whittington et al., 2000); however, it has also been associated with periods of instability or circulation with an increase in the phosphorus concentration (Hart \& Wragg, 2009). The dominance of other large Dinophyceae species, such as $P$. gatunense and $C$. furcoides, has been explained by the resuspension of cysts from the sediment during mixing periods and the suitable conditions for excystation in a turbulent water column with high nutrient concentrations (Berman et al., 1992; Matsumura-Tundisi et al., 2010).

The dominance of $C$. hirundinella in the reservoirs of Chisacá and La Regadera during most of our study can be explained by the large size of this species and its high mobility during stratified periods and moderate turbulence. Generally, the hydraulic management of these reservoirs consists of rapid increases in the water renewal, followed by periods of one or two weeks with a low water renewal. During these short periods of time of high turbulence, $C$. hirundinella can sustain itself in an unstable water column and later become dominant in a water column that stratifies quickly. $P$. cinctum was dominant during stratified and mixing periods in San Rafael and Chuza. $P$. cinctum is a species with a relatively large size (47 $\mu \mathrm{m}$ in its largest linear dimension), commonly found in artificial water bodies and occasionally forming blooms (Wynne et al., 1982). This species has a high capacity for storing phosphorus; thus, in stratification periods, it can maintain important biomass, and during periods of thermal instability, it can profit from the increase in nutrients in the water column (Pollingher \& Serruya, 1976). 
Dinophyceae has species with different specific requirements but with a high plasticity when exposed to a broad range of environmental conditions (Lopes et al., 2009; Cardoso et al., 2010); therefore, these species are able to develop in different reservoir conditions. In the context of the water systems studied here, the physical stability of the water column did not explain the strategies of the dominant species but did explain some of the temporal turnovers among them.

In San Rafael, Desmidiaceae dominated or codominated in the periods of prolonged stratification, when the overall mixing zone showed variations in its amplitude. In tropical lakes, differences in temperature between day and night and wind provoke events of atelomixis that introduce slight variations in the conditions of the water column. These variations can explain the persistence of non-motile algae such as Desmidiaceae during stratified periods (Barbosa \& Padisák, 2002) and the importance of changes of the water renewal rate on the phytoplankton of San Rafael. Small variations in the availability of nutrients and light can also restrain the development of phases of high dominances by a few species and stimulate a temporal turnover in the species of Desmidiaceae (Souza et al., 2008).

In systems with a low tension due to exogenous conditions, factors intrinsic to the system such as seasonal variations in climate and hydrology (Martínez-Almeida \& Tavera, 2005; Rivera et al., 2005; Reyes et al., 2008) and daily variations in radiation and thermal stability (Lewis, 1978; Esteves, 1998; Souza et al., 2008) may regulate the temporal dynamics of plankton. Chuza is the only reservoir where the mixing periods were caused by the combined effects of wind and rain, as has been reported for tropical mountain lakes (Gunkel, 2000; Zapata-Anzola et al., 2006; Donato, 2010); therefore, physical and chemical variables associated with climate seasonality explain an important fraction of the variability of phytoplankton in this system.

Our data show that variation in the water renewal rate is one of the primary factors driving the temporal changes in phytoplankton in the studied reservoirs; nonetheless, the relevance of this factor varied according to the particular con- ditions of the systems, such as the hydraulic management model, the nutrient concentrations, and the development of species that can readily adapt to fluctuating environmental conditions.

\section{ACKNOWLEDGMENTS}

We are grateful to all of the members of the project "Seguimiento limnológico de las fuentes de agua captadas para el suministro realizado por la Empresa de Acueducto y Alcantarillado de Bogotá-E.S.P." carried out by the Empresa de Acueducto y Alcantarillado de Bogotá-E.S.P. and conducted by Dirección de Ingeniería Especializada, Gerencia de Abastecimiento, Planta de Tratamiento Wiesner and Planta de Tratamiento El Dorado. We are also grateful to Laboratorio de Análisis de Aguas for their contributions and support during all phases of the study. The data contained in this article belong to the Empresa de Acueducto y Alcantarillado de Bogotá-ESP. We acknowledge the assistance of Sandra Constantino in translating and copy editing the manuscript.

\section{REFERENCES}

APHA, AWWA \& WEF. 2005. Standard Methods for the Examination of Water and Wastewater. American Public Health Association. Washington D.C., USA. 1325 pp.

BARBOSA, F. A. R. \& J. PADISÁK. 2002. The forgotten lake stratification pattern, and its ecological importance. Verhandlungen Internationale Vereinigung für theoretische und angewandte Limnologie, 25: 1-11.

BECKER, V., L. CAPUTO, J. ORDONEZ, R. MARCE, J. ARMENGOL, L. O. CROSSETTI \& V. L. M. HUSZAR. 2010. Driving factors of the phytoplankton functional groups in a deep Mediterranean reservoir. Water Research, 44: 3345-3354.

BECKER, V., V. L. M. HUSZAR, L. NASELLIFLORES \& J. PADISAK. 2008. Phytoplankton equilibrium phases during thermal stratification in a deep subtropical reservoir. Freshwater Biology, 53: 952-963.

BERMAN, T., Y. Z. YACOBI \& U. POLLINGHER. 1992. Lake Kinneret phytoplankton: Stability 
and variability during twenty years (1970-1989). Aquatic Sciences, 54: 104-127.

BORGES, P. A. F., S. TRAIN \& L. C. RODRIGUES. 2008. Spatial and temporal variation of phytoplankton in two subtropical Brazilian reservoirs. Hydrobiologia, 607: 63-74.

BOUVY, M., S. M. NASCIMENTO, R. J. R. MOLICA, A. FERREIRA, V. HUSZAR \& S. M. F. O. AZEVEDO. 2003. Limnological features in Tapacurá reservoir (northeast Brazil) during a severe drought. Hydrobiologia, 493: 115-130.

CARDOSO, L. D., P. B. FAGUNDES \& V. BECKER. 2010. Spatial and temporal variations of Dinophyceae in subtropical reservoirs in southern Brazil. Hydrobiologia, 654: 205-214.

COLE, G. A. 1994. Textbook of Limnology. Waveland Press, Inc. Long Grove, USA. 412 pp.

CHELlAPPA, N. T., T. CHELLAPPA, F. R. A. CÂMARA, O. ROCHA \& S. CHELLAPPA. 2009. Impact of stress and disturbance factors on the phytoplankton communities in Northeastern Brazil reservoir. Limnologica, 39: 273-282.

DONATO, J. 2010. Phytoplankton of Andean Lakes in Northern South America (Colombia). A. R. G. Gantner Verlag K. G. Ruggell, Liechtenstein. $419 \mathrm{pp}$.

ESTEVES, F. A. 1998. Fundamentos de Limnologia. Interciencia. Sao Pablo, Brazil. 602 pp.

GAYTAN-HERRERA, M. L., V. MARTINEZ-ALMEIDA, M. G. OLIVA-MARTINEZ, A. DURAN-DIAZ \& P. RAMIREZ-GARCIA. 2011. Temporal variation of phytoplankton from the tropical reservoir Valle de Bravo, Mexico. Journal of Environmental Biology, 32: 117-126.

GOMES, L. C. \& L. E. MIRANDA. 2001. Hydrologic and climatic regimes limit phytoplankton biomass in reservoirs of the Upper Paraná River Basin, Brazil. Hydrobiologia, 457: 205-214.

GUNKEL, G. 2000. Limnology of an Equatorial High Mountain Lake in Ecuador, Lago San Pablo. Limnologica, 30: 113-120.

HARRIS, G. P. 1986. Phytoplankton Ecology. Structure Function and Fluctuation. Chapman and Hall. London, UK. 384 pp.

HART, R. C. \& P. D. WRAGG. 2009. Recent blooms of the dinoflagellate Ceratium in Albert Falls Dam $(\mathrm{KZN})$ : History, causes, spatial features and impacts on a reservoir ecosystem and its zooplankton. Water SA, 35: 455-468.

INTERLANDI, S. J. \& S. S. KILHAM. 2001. Limiting resources and the regulation of diversity in phytoplankton communities. Ecology, 82: 12701282.

JENSEN, J. P., E. JEPPESEN, K. OLRIK \& P. KRISTENSEN. 1994. Impact of nutrients and physical factors on the shift from cyanobacterial to chlorophyte dominance in shallow Danish lakes. Canadian Journal of Fisheries and Aquatic Sciences, 51: 1692-1699.

JONGMAN, R. H. G., C. J. F. TER BRAAK \& O. F. R. VAN TONGEREN (ed.). 1995. Data analysis in community and landscape ecology. Cambridge University Press. Cambridge, UK. 301.

JOST, L. 2007. Partitioning diversity into independent alpha and beta components. Ecology, 88: 24272439.

KRUK, C., V. L. M. HUSZAR, E. T. H. M. PEETERS, S. BONILLA, L. COSTA, M. LÜRLING, C. S. REYNOLDS \& M. SCHEFFER. 2010. A morphological classification capturing functional variation in phytoplankton. Freshwater Biology, 55: 614-627.

LEWIS, W. M. J. 1973. Thermal regime of lake Lanao (Philipphines) and its theoretical implications for tropical lakes. Limnology and Oceanography, 18: 200-217.

LEWIS, W. M. J. 1978. Dynamics and succession of the phytoplankton in a tropical lake: Lake Lanao, Philippines. Journal of Ecology, 66: 849-880.

LEWIS, W. M. J. 2000. Basis for the protection and management of tropical lakes. Lakes and Reservoirs: Research and Management, 5: 35-48.

LOPES, M. R., C. FERRAGUT \& C. E. M. BICUDO. 2009. Phytoplankton diversity and strategies in regard to physical disturbances in a shallow, oligotrophic, tropical reservoir in Southeast Brazil. Limnetica, 28: 159-174.

MAC DONAGH, M. E., M. A. CASCO \& M. C. CLAPS. 2009. Plankton relationships under small water level fluctuations in a subtropical reservoir. Aquatic Ecology, 43: 371-381.

MARGALEF, R. 1983. Limnología. Omega. Barcelona, Spain. 1010 pp.

MARTÍNEZ-ALMEIDA, V. \& R. TAVERA. 2005. A hydrobiological study to interpret the presence of desmids in Lake Zirahuén, México. Limnologica, 35: 61-69.

MATSUMURA-TUNDISI, T., J. G. TUNDISI, A. P. LUZIA \& R. M. DEGANI. 2010. Occurrence of Ceratium furcoides (Levander) Langhans 1925 bloom at the Billings Reservoir, São Paulo 
State, Brazil. Ocorrência de floração de Ceratium furcoides (Levander) Langhans 1925, na represa Billings, Estado de São Paulo, Brasil, 70: 825-829.

NASELLI-FLORES, L. 2000. Phytoplankton assemblages in twenty-one Sicilian reservoirs: relationships between species composition and environmental factors. Hydrobiologia, 424: 1-11.

NASELLI-FLORES, L. \& R. BARONE. 2005. Waterlevel fluctuations in Mediterranean reservoirs: Setting a dewatering threshold as a management tool to improve water quality. Hydrobiologia, 548: 8599.

NASELLI-FLORES, L., J. PADISÁK \& M. ALBAY. 2007. Shape and size in phytoplankton ecology: Do they matter? Hydrobiologia, 578: 157-161.

PACHECO, J. P., C. IGLESIAS, M. MEERHOFF, C. FOSALBA, G. GOYENOLA, F. TEIXEIRA-DE MELLO, S. GARCÍA, M. GELÓS \& F. GARCÍA-RODRÍGUEZ. 2010. Phytoplankton community structure in five subtropical shallow lakes with different trophic status (Uruguay): A morphologybased approach. Hydrobiologia, 646: 187-197.

PADISAK, J., E. HAJNAL, L. NASELLI-FLORES, M. T. DOKULIL, P. NOGES \& T. ZOHARY. 2010. Convergence and divergence in organization of phytoplankton communities under various regimes of physical and biological control. $\mathrm{Hy}$ drobiologia, 639: 205-220.

PANNARD, A., M. BORMANS \& Y. LAGADEUC. 2008. Phytoplankton species turnover controlled by physical forcing at different time scales. Canadian Journal of Fisheries and Aquatic Sciences, 65: 47-60.

POLLINGHER, U. \& C. SERRUYA. 1976. Phased division of Peridinium cinctum fa. Westii and the development of blooms in Lake Kinneret. Journal of Phycology, 11: 155-162.

REYES, I., M. A. CASCO, J. TOJA \& L. SERRANO. 2008. Hydrological complexity supports high phytoplankton richness in the Doñana marshland (SW Spain). Hydrobiologia, 614: 47-54.

REYNOLDS, C. S. 1984. The ecology of freshwater phytoplankton. Cambridge University Press. Cambridge, UK. 384 pp.

REYNOLDS, C. S. 1997. Vegetation processes in the pelagic: A model for ecosystem theory. Ecology Institute. Luhe, Germany. 371 pp.

REYNOLDS, C. S. 2006. The Ecology of Phytoplankton (Ecology, Biodiversity and Conservation).
Cambridge University Press. Cambridge, UK. $552 \mathrm{pp}$.

RIVERA, C., D. SOLANO, A. ZAPATA \& J. DONATO. 2005. Phytoplankton diversity in a tropical high mountain lake. Verhandlungen Internationale Vereinigung für theoretische und angewandte Limnologie, 29: 418-421.

SEELIGMANN, C. \& B. C. TRACANNA. 2009. Phytoplankton dynamics in a high elevation reservoir of Northwestern Argentina (Tucuman). Limnetica, 28: 105-124.

SOARES, M. C., M. M. MARINHO, V. L. M. HUSZAR, C. BRANCO \& S. AZEVEDO. 2008. The effects of water retention time and watershed features on the limnology of two tropical reservoirs in Brazil. Lakes \& Reservoirs: Research \& Management, 13: 257-269.

SOARES, M. C. S., L. O. VIDAL, F. ROLAND \& V. L. M. HUSZAR. 2009. Cyanobacterial equilibrium phases in a small tropical impoundment. Journal of Plankton Research, 31: 1331-1338.

SOMMER, U., J. PADISÁK, C. S. REYNOLDS \& P. JUHÁSZ-NAGY. 1993. Hutchinson's heritage: the diversity-disturbance relationship in phytoplankton. Hydrobiologia, 249: 1-7.

SOUZA, M. B. G., C. F. A. BARROS, F. BARBOSA, E. HAJNAL \& J. PADISAK. 2008. Role of atelomixis in replacement of phytoplankton assemblages in Dom Helvecio Lake, South-East Brazil. Hydrobiologia, 607: 211-224.

SUN, J. \& D. LIU. 2003. Geometric models for calculating cell biovolume and surface area for phytoplankton. Journal of Plankton Research, 25: 13311346.

TOLOTTI, M., A. BOSCAINI \& N. SALMASO. 2010. Comparative analysis of phytoplankton patterns in two modified lakes with contrasting hydrological features. Aquatic Sciences - Research Across Boundaries, 72: 213-226.

TOWNSEND, S. A. 2001. Perennial domination of phytoplankton by Botryococcus and Peridinium in a discontinuously polymictic reservoir (tropical Australia). Archiv Fur Hydrobiologie, 151: 529548.

TOWNSEND, S. A. \& J. T. LUONG-VAN. 1998. Phytoplankton biomass and composition in Manton River Reservoir, a mesotrophic impoundment in the Australian wet/dry tropics. International Review of Hydrobiology, 83: 113-120.

TUNDISI, J. G., T. MATSUMURA-TUNDISI \& D. S. ABE. 2008. The ecological dynamics of Barra 
Bonita (Tietê River, SP, Brazil) reservoir: Implications for its biodiversity. Brazilian Journal of Biology, 68: 1079-1098.

UTERMÖHL, H. 1958. Zur vervollkommung der quantitativen phytoplankton-Methodik. Mitteilungen der Internationale Vereinigung für Theoretische und Angewandte Limnologie, 9: 1-38.

WACKLIN, P., L. HOFFMANN \& J. KOMÁREK. 2009. Nomenclatural validation of the genetically revised cyanobacterial genus Dolichospermum (Ralfs ex Bornet et Flahault) comb, nova. Fottea, 9: 59-64.

WETZEL, R. G. \& G. E. LIKENS. 2000. Limnological Analyses. Springer-Verlag. New York, USA. 429 pp.

WHITTINGTON, J., B. SHERMAN, D. GREEN \& R. L. OLIVER. 2000. Growth of Ceratium hi- rundinella in a subtropical Australian reservoir: The role of vertical migration. Journal of Plankton Research, 22: 1025-1045.

WYNNE, D., N.J. PATNI, S. AARONSON \& T. BERMAN. 1982. The relationship between nutrient status and chemical composition of Peridinium cinctum during the bloom in Lake Kinneret. Journal of Plankton Research, 4: 125-136.

ZAPATA-ANZOLA, A. M., C. A. RIVERA-RONDÓN \& J. C. DONATO-RONDÓN. 2006. Dynamics of photosynthetic pigments in an Andean lake in Colombia. Lakes and Reservoirs: Research and Management, 11: 29-38.

ZOHARY, T., J. PADISÁK \& L. NASELLI-FLORES. 2010. Phytoplankton in the physical environment: beyond nutrients, at the end, there is some light. Hydrobiologia, 639: 261-269. 